\title{
O campo e a cidade em Machado e Eça: uma leitura comparativa de A Cidade e as Serras e "A Parasita Azul”
}

\section{The countryside and the city in Machado and Eça: a comparative reading of A Cidade $e$ as Serras and "A Parasita Azul"}

\section{Greicy Pinto Bellin* \\ $U F P R$}

Resumo: o objetivo do presente artigo é analisar as representações do campo e da cidade em A Cidade e as Serras, de Eça de Queirós, publicado em 1901, e “A parasita azul”, de Machado de Assis, publicado no periódico Jornal das Famílias, em 1872. Em ambas as narrativas, observa-se que os personagens principais definem suas existências a partir de relações estabelecidas com os ambientes rural e urbano, e que tais relações terão consequências diretas em suas vidas sentimentais. Constata-se também a predominância de um fascínio em relação à vida cosmopolita, o que se justifica, nos contextos de produção das narrativas, pelo advento da modernidade, do avanço tecnológico e de novas formas de sociabilidade. A análise tenciona mostrar, a partir das considerações de autores como Antonio Candido e Pascale Casanova, que tanto Machado quanto Eça tecem, cada um à sua maneira, uma crítica ao modo de vida associado ao cosmopolitismo e à modernidade parisiense, objeto de verdadeiro encantamento por parte de intelectuais brasileiros e de portugueses no século XIX.

Palavras-chave: Campo. Cidade. Modernidade. Cosmopolitismo.

\begin{abstract}
: this article's aim is to analyze the representations of the countryside and the city in A Cidade e as Serras, by Eça de Queirós, published in 1901, and "A parasita azul”, by Machado de Assis, published in the newspaper Jornal das Famílias, in 1872. In both narratives, it is possible to observe that the main characters define their existences based on relations established with the rural and urban environments, and that such relations have direct consequences on their sentimental lives. It is also possible to observe the predominance of a fascination in relation to cosmopolitan life, which is justified, in the contexts where the narratives have been produced, by the emergence of modernity, technological advance and new forms of sociability. Based on considerations from Antonio Candido and Pascale Casanova, this analysis intends to show that both Machado and Eça criticize the forms of life that were associated with cosmopolitanism and Parisian modernity, which was object of a true enchantment by Brazilian and Portuguese intellectuals in the nineteenth century.
\end{abstract}

Keywords: Field. City. Modernity. Cosmopolitanism.

\author{
${ }^{*}$ Doutora em Estudos \\ Literários pela \\ Universidade Federal \\ do Paraná \\ greicybellin@ \\ hotmail.com
}


O campo e a cidade em Machado e Eça: uma leitura comparativa de A Cidade e as Serras e "A Parasita Azul”

\section{Introdução}

Tanto Machado de Assis quanto Eça de Queirós são escritores de fundamental importância para as literaturas brasileira e portuguesa do século XIX. Ambos são constantemente associados à estética realista, tendo veiculado, por meio de suas obras, representações cruas e desencantadas do contexto social da época na qual estavam inseridos. Tais representações também se encontram relacionadas ao campo e à cidade, conforme podemos observar em A Cidade e as Serras, de 1901, e “A parasita azul”, publicado em 1872 no periódico Jornal das Famílias. As figurações eciana e machadiana dos ambientes rural e urbano nos permitem perceber uma postura crítica em relação aos avanços trazidos pela modernidade e pelo avanço tecnológico, postura esta que pretendemos analisar no presente artigo.

As relações literárias entre Machado e Eça têm sido fartamente comentadas e esmiuçadas pela crítica literária brasileira com base na célebre crítica machadiana ao romance $O$ primo Basílio, publicada em 1878 no jornal $O$ Cruzeiro. $O$ ensaio consiste em um dos pontos altos do exercício crítico do autor de Memórias póstumas de Brás Cubas, em que ele aponta as falhas estruturais do romance de Eça em uma perspectiva tida como moralmente conservadora, na qual o adultério de Luísa é visto como um fato desnecessário e vulgar. Na visão de Paulo Franchetti, o texto de Machado foi responsável por orientar, até hoje, a recepção crítica do romance eciano, lançando formulações "tomadas como verdades evidentes, definitivas e de ordem exclusivamente estética.” (FRANCHETTI, 2008, p. 270). Daí a importância de se analisar as relações entre os dois escritores, especialmente se atentarmos para o fato de que, de acordo com João Cezar de Castro Rocha, a crítica de Machado "teria acertado em pontos estratégicos”, sendo também “decisiva na correção dos rumos do próprio Eça.” (ROCHA, 2011, p. 125). Tais relações, entretanto, não se restringem apenas ao âmbito da crítica literária, englobando uma série de aspectos que têm sido pouco analisados em Machado e Eça, entre eles o contraponto entre campo e cidade e a problematização da ideia de modernidade parisiense, aspectos estes presentes tanto em A Cidade e as Serras quanto em "A parasita azul”.

A dicotomia entre espaço urbano e espaço rural, juntamente com as representações da vida cosmopolita, são temas de fundamental importância na literatura do século XIX devido, entre outros fatores, ao advento da modernidade, que traz alterações significativas nos modos de sociabilidade e confronta o sujeito com novas concepções de individualidade, tensionando sua percepção de mundo e alterando as percepções relativas ao espaço. Este é muitas vezes representado de forma ambivalente, como objeto de fascínio e ao mesmo tempo, de perdição, sendo que o campo, por outro lado, tende a ser visto como local de redenção e purificação. Raymond Williams, em sua análise sobre a literatura inglesa do século XVIII, aponta para a existência de uma "estrutura de sentimentos" que contrasta campo e cidade, "estru- 
tura” esta que percebe o campo como lugar de inocência e a cidade como ambiente mundano e permissivo, em um "contraste retórico" cristalizado desde a Antiguidade clássica. (WILLIAMS, 1989, p. 69). Sobre a autonomia da cidade, Williams afirma que "essa vida fervilhante de lisonja e suborno, de sedução organizada, de barulho e tráfego, com ruas perigosas por causa dos ladrões, com casas frágeis e amontoadas, sempre ameaçadas de incêndio, é a cidade como algo autônomo, seguindo seu próprio caminho.” (WILLIAMS, 1989, p. 70). O refúgio para o ambiente rural é percebido como alívio para aqueles que querem se afastar da vida mundana, atitude observada no personagem Jacinto de A Cidade e as Serras, o que reforçaria os estereótipos de inocência e de virtudes simples associados ao campo. Para Raymond Williams, estas ideias e imagens do campo e da cidade ainda conservam sua força acentuada, em uma significativa persistência que nada mais é do que "uma das principais maneiras de adquirirmos consciência de uma parte central de nossa experiência e das crises de nossa sociedade.” (WILLIAMS, 1989, p. 387). Tais percepções serão questionadas e até mesmo, problematizadas por Machado e Eça em suas narrativas, de maneira a evidenciar uma postura crítica em relação a uma modernidade associada à metrópole parisiense.

Esta associação faz sentido se levarmos em consideração o fato de que a França havia se tornado, no século XIX, um verdadeiro símbolo de modernidade. Pascale Casanova, em A República Mundial das Letras, aponta para a existência de um “discurso hiperbólico sobre Paris”, caracterizado por descrições de revoluções e levantes populares, que "condensam de certa forma todas as representações sobre as quais repousa a lenda de Paris.” (CASANOVA, 2002, p. 43). O modelo de modernidade associado à França, por sua vez, é expresso pelos dizeres de Victor Hugo em um artigo de 1867: "Meu desafio aos senhores é usar outro chapéu que não o de Paris. A fita dessa mulher que passa governa. Em todos os países, a maneira como essa fita está amarrada é lei.” (HUGO, apud CASANOVA, 2002, p. 117). A crença na onipotência francesa passou a ser reconhecida como universal, perdurando por muito tempo no meio cultural europeu e também, no brasileiro. Tal crença transparece nas narrativas que serão analisadas no presente capítulo, mais especificamente nas posturas de Jacinto e Camilo Seabra, que forjam um modelo de comportamento totalmente identificado com o glamour da vida parisiense, evidenciando uma assimilação passiva e acrítica de tal modelo. De fato, o prestígio cultural da França era inegável tanto no Brasil quanto em Portugal, considerando as posições ocupadas por tais países no cenário internacional oitocentista. No caso do Brasil, a francofilia era tão intensa que, de acordo com Sandra Vasconcelos (2011), a maioria dos romances importados era traduzida a partir do francês, língua que se tornou a legitimadora de discursos e mediadora de relações culturais. As narrativas de Machado e Eça nos fornecem pistas concretas de uma grande dependência em relação aos modelos literários franceses, problematizada 
a partir da ida dos personagens para o campo, que marca não apenas uma mudança em suas vidas amorosas como também o redimensionamento de uma visão de mundo segundo a qual a vida cosmopolita seria a única fonte de felicidade para o sujeito.

A presença do ambiente rural é um dos aspectos que mais chama a atenção em “A parasita azul” especialmente se considerarmos que a obra machadiana prima pela descrição da vida urbana na corte do Rio de Janeiro. Na visão de John Gledson, “A parasita azul” "é um dos raros contos de Machado que saem do Rio; ainda mais excepcional, ele vai ao sertão.” (GLEDSON, 2008, p. 203). A princípio, a representação do sertão brasileiro poderia ser vista como uma tentativa de conferir cor local à narrativa, mas para Gledson isso não se observa, uma vez que o sertão de Machado é “deliberadamente apoético.” (GLEDSON, 2008, p. 203). Na visão de Cristóvão Tezza, o olhar de Machado para o interior do país é absolutamente neutro e desprovido de adornos valorativos. O autor cita como exemplo a novela "O alienista", em que o "mundo exótico” do interior do Brasil é deslocado para a loucura do projeto de Simão Bacamarte, contrariando as veleidades dos romances regionalistas da época. (TEZZA, 2008, p. 245). Algo semelhante pode ser observado em “A parasita azul”, em que o interior de Goiás não é visto com as lentes do nacionalismo ufanista, e sim como um articulador do dilema existencial e sentimental enfrentado pelo protagonista.

Antonio Candido, no célebre ensaio Entre campo e cidade, afirma que a obra de Eça de Queirós “se apresenta em grande parte como diálogo entre campo e cidade - ora predominando a nota urbana, ora fazendo-se ouvir mais forte a nota rural.” (CANDIDO, 1978, p. 31). Tal dicotomia viria a acompanhar toda a obra eciana, de forma que $O$ primo Basílio, por exemplo, é classificado por Candido como "romance da capital". O autor ainda destaca a postura crítica de Eça em relação à assimilação passiva de modelos estrangeiros, considerando que o "burguês lisboeta", por se encontrar em um fogo cruzado entre o urbano e o rural, não consegue "forjar um estilo original de vida ou de pensamento.” (CANDIDO, 1978, p. 36). Para Candido, A Cidade e as Serras seria uma espécie de "anti-Basílio", realizando uma verdadeira "apoteose da Serra sobre a Cidade”, em uma “filosofia neuroticamente urbana” que se assemelha à Correspondência de Fradique Mendes, outra narrativa de Eça na qual transparece o fascínio pela “civilização”. (CANDIDO, 1978, p. 45-46).

Na visão de João Medina (1974), A Cidade e as Serras é um libelo pessimista contra a cidade e contra a imitação do modelo estrangeiro, correspondendo à terceira fase da produção de Eça, representada por narrativas nas quais o caminho de volta para o campo é apontado como solução para os problemas da pátria portuguesa. A postura crítica do escritor aparece sintetizada não apenas em Jacinto, mas no próprio José Fernandes, que seria, para Antonio Candido (1978), um "arauto da volta ao campo”, sinalizando 
as dificuldades experimentadas por Portugal em se ajustar ao ritmo intenso e frenético da modernização. Talvez a mesma crítica esteja presente em "A parasita azul”, considerando a posição ocupada por Brasil e Portugal diante da hegemonia cultural francesa representativa da modernidade e dos avanços tecnológicos observados ao longo do século XIX.

\section{A Cidade e as Serras, “A parasita azul” e o contraponto entre campo e cidade}

A Cidade e as Serras, publicado um ano após a morte de Eça de Queirós, desenvolve a ideia central do conto "Civilização”, de 1892. O romance é narrado em primeira pessoa por José Fernandes, que relata o cotidiano de seu amigo Jacinto, um verdadeiro amante da vida citadina que decide ir viver no campo. O personagem central é um adepto do progresso, o que se manifesta no entusiasmo em relação ao avanço tecnológico e na rejeição a um mundo natural que será, mais tarde, exaltado pelo próprio Jacinto. Tal característica é enfatizada por Fernandes já no capítulo de abertura do romance, em que narra seu primeiro encontro com Jacinto em Paris:

Ora nesse tempo Jacinto concebera uma ideia.... Este príncipe concebera a ideia de que o homem só é "superiormente feliz quando é superiormente civilizado”. E por homem civilizado o meu camarada entendia aquele que, robustecendo a sua força pensante em todas as noções adquiridas desde Aristóteles, e multiplicando a potência corporal dos seus órgãos com todos os mecanismos inventados desde Teramenes, criador da roda, se torna um magnífico Adão quase onipotente, quase onisciente, e apto portanto a recolher dentro de uma sociedade e nos limites do progresso (tal como ele se comportava em 1875) todos os gozos e todos os proventos que resultam de saber e de poder.... Pelo menos assim Jacinto formulava copiosamente a sua ideia, quando conversávamos de fins e destinos humanos, sorvendo bocks poeirentos, sob o toldo das cervejarias filosóficas, no Bouvelard Saint-Michel. (QUEIRÓS, 1995, p. 22).

É com base nesta ideia que Jacinto irá desenvolver seu apego à modernidade e ao avanço tecnológico, ao passo que José Fernandes volta a viver no campo a pedido de seu tio Afonso, provocando no protagonista uma reação negativa: “Para Guiães!... Oh Zé Fernandes, que horror!” (QUEIRÓS, 1995, p. 30). Após a morte do tio, Fernandes retorna a Paris e encontra seu amigo totalmente imerso na tecnologia e na vida cosmopolita, conforme demonstra o trecho a seguir:

Mas dentro, no peristilo, logo me surpreendeu um elevador instalado por Jacinto - apesar do 202 ter somente dois andares, e ligados por uma escada tão doce que nunca ofendera a asma da Sra. D. Angelina! Espaçoso, tapetado, ele oferecia, para aquela jornada de sete segundos, confortos numerosos, um divã, uma pele de urso, um roteiro das ruas de Paris, prateleiras 
gradeadas com charutos e livros. Na antecâmara, onde desembarcamos, encontrei a temperatura macia e tépida de uma tarde de maio, em Guiães. Um criado, mais atento ao termômetro que um piloto à agulha, regulava destramente a boca dourada do calorífero. E perfumadores entre palmeiras, como num terraço santo de Benares, esparziam um vapor, aromatizado e salutarmente umedecendo aquele ar delicado e superfino. Eu murmurei, nas profundidades do meu assombrado ser: - Eis a civilização! (QUEIRÓS, 1995, p. 32-33).

O fascínio pela “civilização” está também presente em “A parasita azul”. Após oito anos estudando medicina na Europa, Camilo Seabra retorna a Goiás por insistência de seu pai, o comendador Seabra. Ao desembarcar no Brasil, o protagonista aparenta tristeza, uma vez que fora obrigado a abandonar a vida que tanto lhe agradava:

Não abonava muito os seus sentimentos patrióticos o rosto com que entrou a barra da capital brasileira. Trazia-o fechado e merencório, como quem abafa em si alguma coisa que não é exatamente a bem-aventurança terrestre. Arrastou um olhar aborrecido pela cidade, que se ia desenrolando à proporção que o navio se dirigia ao ancoradouro. Quando veio a hora de desembarcar, fê-lo com a mesma alegria com que o réu transpõe os umbrais do cárcere. O escaler afastou-se do navio em cujo mastro flutuava uma bandeira tricolor. Camilo murmurou consigo: - Adeus, França! (ASSIS, 2008, p. 145).

É possível perceber um apego intenso à metrópole cosmopolita, frequentemente comparada à vida pacata no interior de Goiás, que carece das vantagens e atrativos de uma cidade como Paris. Tais impressões são reforçadas pelo narrador machadiano, que faz questão de ressaltar o sofrimento de Camilo ao voltar para o Brasil: "Jantou solitário a triste com a mente cheia de mil recordações do mundo que acabava de deixar, e para dar ainda maior desafogo à memória, apenas acabado o jantar, estendeu-se num canapé, e começou a desfiar consigo mesmo um rosário de cruéis desventuras.” (ASSIS, 2008, p. 145). Verifica-se, no entanto, que ao longo da narrativa o narrador desfaz com profundo sarcasmo e ironia a suposta superioridade do protagonista, no sentido de mostrar que Paris não fora capaz de formar um médico respeitável e sim, um sujeito dado à vida boêmia e dissoluta, conforme se observa no trecho a seguir:

A escala toda dos prazeres sensuais e frívolos foi percorrida por este esperançoso mancebo com uma sofreguidão que parecia antes suicídio. Seus amigos eram numerosos, solícitos e constantes; alguns não duvidavam dar-lhe a honra de o constituir seu credor. Entre as moças de Corinto era o seu nome verdadeiramente popular; não poucas o tinham amado até o delírio. Não havia pateada célebre em que a chave dos seus aposentos não figurasse, nem corrida, nem ceata, nem passeio, em que não ocupasse um dos primeiros lugares cet aimable brésilien. (ASSIS, 2008, p. 147). 
Cabe ressaltar que este não havia sido o futuro idealizado pelo comendador Seabra quando este elegeu um padrinho francês para seu filho: “(...) se este pequeno vingar, hei de mandá-lo para a sua terra, a aprender medicina ou qualquer outra coisa em que se faça homem.” (ASSIS, 2008, p. 146). Forja-se, dessa maneira, um pensamento, arraigado no seio da elite brasileira oitocentista, segundo o qual a França seria o local propício para o enriquecimento cultural e intelectual do cidadão, que, ao fim e ao cabo, acaba não usufruindo da experiência europeia para se tornar um homem respeitável. Observa-se, além disso, uma representação do ambiente citadino como algo frívolo e permissivo, que envolve o sujeito a ponto de causar-lhe dificuldades de se libertar da vida boêmia para retornar à sua terra natal.

A frivolidade também transparece em A Cidade e as Serras, mais especificamente no modo de vida levado por Jacinto no apartamento 202, decorado e mobiliado de forma a evidenciar a existência de um dândi:

Ele erguera uma tapeçaria - entramos no seu gabinete de trabalho, que me inquietou. Sobre a espessura dos tapetes sombrios os nossos passos perderam logo o som, e como a realidade. O damasco das paredes, os divãs, as madeiras, eram verdes, de um verde profundo de folha de louro. Sedas verdes envolviam as luzes elétricas, dispersas em lâmpadas tão baixas que lembravam estrelas caídas por cima das mesas, acabando de arrefecer e morrer; só uma rebrilhava nua e clara, no alto de uma estante quadrada, esguia, solitária como uma torre numa planície, e de que o lume parecia ser o farol melancólico. Um biombo de laca verde, fresco verde de relva, resguardava a chaminé de mármore verde, verde de mar sombrio, onde esmoreciam as brasas de uma lenha aromática. E entre aqueles verdes reluzia, por sobre peanhas e pedestais, toda uma máquina suntuosa, aparelhos, lâminas, rodas, tubos, engrenagens, hastes, friezas, rigidezas de metais... (QUEIRÓS, 1995, p. 33-34).

Vale ressaltar que a figura do dândi é uma das mais emblemáticas da literatura moderna, aparecendo no romance Às avessas, de J.K. Huysmans, mais especificamente na figura de Des Esseintes, e na obra de Baudelaire. Em A Cidade e as Serras, o dandismo de Jacinto aparece associado à sofisticação da vida cosmopolita parisiense, percebida a princípio com fascínio e mais tarde, com o distanciamento que acabará motivando a ida do protagonista para o campo. Indícios de tal postura transparecem no terceiro capítulo da narrativa, em que, ao passear com José Fernandes por Paris, Jacinto se mostra impaciente e até mesmo cansado de viver na metrópole:

Quando o dia social de Jacinto se apresentava mais desafogado, e o céu de março nos concedia carinhosamente um pouco de azul aguado, saíamos depois do almoço, a pé, através de Paris. Estes lentos e errantes passeios eram outrora da nossa idade de estudantes, um gozo muito querido de Jacinto - porque neles mais intensamente e mais minuciosamente saboreava a cidade. Agora porém, apesar da minha companhia, só lhe 
davam uma impaciência e uma fadiga que desoladoramente destoava do antigo, iluminado êxtase. Com espanto (...) descobri eu, na primeira tarde em que descemos aos boulevards, que o denso formigueiro humano sobre o asfalto, e a torrente sombria dos trens sobre o macadame, afligiam o meu amigo pela brutalidade da sua pressa, do seu egoísmo, e do seu estridor. Encostado e como refugiado no meu braço, este Jacinto novo começou a lamentar que as ruas, na nossa civilização, não fossem calçadas de gutapercha! E a guta-percha claramente representava, para o meu amigo, a substância discreta que amortece o choque e a rudeza das coisas! Oh maravilha! Jacinto querendo borracha, a borracha isoladora, entre a sua sensibilidade e as funções da cidade! (QUEIRÓS. 1995, p. 47).

Percebem-se, a partir da leitura do trecho acima, sinais concretos de uma percepção crítica acerca da vida citadina, ao contrário do que ocorre no início de “A parasita azul”, em que o ambiente urbano é visto com grande deslumbramento por Camilo Seabra. A crítica parte do próprio José Fernandes, que concorda com Jacinto no tocante à feiura de Paris:

Nessa mesma tarde, se bem recordo, sob uma luz macia e fina, penetramos nos centros de Paris, nas ruas longas, nas milhas de casario, todo de caliça parda, erriçado de chaminés de lata negra, com as janelas sempre fechadas, as cortininhas sempre corridas, abafando, escondendo a vida. Só tijolo, só ferro, só argamassa, só estuque: linhas hirtas, ângulos ásperos: tudo seco, tudo rígido. E dos chãos aos telhados, por toda a fachada, tapando as varandas, comendo os muros, tabuletas, tabuletas.... (QUEIRÓS, 1995, p. 48).

Na narrativa machadiana, por outro lado, Camilo se mostra saudoso da vida boêmia parisiense, tecendo frequentes comparações entre Paris e o Rio de Janeiro, reforçando a posição desvantajosa da corte fluminense:

Tudo lhe parecia lúgubre, acanhado, mesquinho. Olhou com desdém olímpico para todas as lojas da rua do Ouvidor, que lhe pareceu apenas um beco muito comprido e muito iluminado. Achava os homens deselegantes, as senhoras desgraciosas. Lembrou-se, porém, que Santa Luzia, sua cidade natal, era ainda menos parisiense que o Rio de Janeiro, e então, abatido com esta importuna ideia correu para o hotel e deitou-se a dormir. (ASSIS, 2008, p. 148).

O deslumbramento em relação à capital francesa é reforçado pela existência de um caso amoroso com Leontina Caveau, interrompido pela volta peremptória de Camilo ao Brasil. A figura feminina é, aliás, uma das responsáveis pela articulação do contraponto entre campo e cidade, tanto na narrativa de Machado quanto em A Cidade e as Serras. Constata-se que a mulher citadina é associada ao vício e à corrupção, algo que transparece, por exemplo, nos Quadros parisienses de Baudelaire, mais especificamente em “A uma mendiga ruiva” e "As velhinhas”, entre outros poemas. Tal associação se torna clara quando José Fernandes narra seu encontro com 
madame Colombe, uma “criatura seca, muito morena, quase tisnada, com dois fundos olhos taciturnos e tristes, e uma mata de cabelos amarelados, toda crespa e rebelde, sob o chapéu velho de plumas negras.” (QUEIRÓS, 1995, p. 84-85). Trata-se de uma paixão fulminante, percebida por Fernandes de forma negativa, uma vez que o retira de sua zona de conforto, fazendo-o perder o controle sobre si mesmo:

Desses dias de sublime sordidez só conservo a impressão de uma alcova forrada de cretones sujos, de uma bata de lã cor de lilás com sutaches negros, de vagas garrafas de cerveja no mármore de um lavatório, e de um corpo tisnado que rangia e tinha cabelos no peito. E também me resta a sensação de incessantemente e com arroubado deleite me despojar, arremessar para um regaço, que se cavava entre um ventre sumido e uns joelhos agudos, o meu relógio, os berloques, os meus anéis, os meus botões de punho de safira, e as cento e noventa e sete libras de ouro que eu trouxera de Guiães numa cinta de camurça. Do sólido, decoroso, bem fornecido Zé Fernandes, só restava uma carcaça errando através de um sonho, com as gâmbias moles e a baba a escorrer. (QUEIRÓS, 1995, p. 86).

Ao descobrir que foi abandonado pela amante, Fernandes sente tremer o seu ser “como se o chão de Paris tremesse”. (QUEIRÓS, 1995, p. 87). Madame Colombe é assim associada aos desvãos e mistérios da metrópole cosmopolita, o que se torna claro nesta outra passagem do romance, em que o personagem narrador se considera curado de sua paixão pela moça: " $E$ concluí que padecera de uma longa sezão, sezão da carne, sezão da imaginação, apanhada num charco de Paris - nesses charcos que se formam através da cidade com as águas mortas, os limos, os lixos, os tortulhos e os vermes de uma civilização que apodrece.” (QUEIRÓS, 1995, p. 89). Tal associação nos dá margem para interpretar as representações da cidade e também da figura feminina como ambíguas, capazes de fascinar e ao mesmo tempo, de atraiçoar o sujeito. Esta associação também aparece ao final de “A parasita azul”, em que Camilo descobre que Leontina Caveau, a moça que tanto o encantara, era na realidade uma ladra de joias. A índole duvidosa de Leontina pode ser verificada na seguinte passagem do conto:

(...) a princesa russa de quem falo, afirmavam algumas pessoas que era filha da rua do Bac e trabalhara numa casa de modas até a revolução de 1848. No meio da revolução apaixonou-se por ela um major polaco, que a levou para Varsóvia, donde acabava de chegar transformada em princesa, com um nome acabado em ine ou off, não sei bem. Vivia misteriosamente, zombando de todos os seus adoradores, exceto de Camilo, dizia ela, por quem sentia que era capaz de aposentar as suas roupas de viúva. Tão depressa, porém, soltava estas expressões irrefletidas, como logo protestava com os olhos no céu:

-Oh! não! nunca, meu caro Alexis, nunca desonrarei a tua memória unindo-me a outro. (ASSIS, 2008, p. 148). 
John Gledson, em sua análise de “A parasita azul” (2008), afirma que Leontina em muito se assemelha à Marcela de Memórias póstumas de Brás Cubas, pois possui a pretensão de pertencer a um ambiente heroico, conforme evidencia o seu suposto envolvimento com um major durante a revolução de 1848. Percebe-se que a moça manipula Camilo para que este continue a cortejá-la, sem, no entanto, dar-lhe qualquer garantia de que irá de fato se envolver com ele. É também possível constatar, ao longo da narrativa, que a figura de Leontina é frequentemente associada à capital francesa, ao passo que Isabel Matos, por quem Camilo se apaixonará, será associada ao ambiente rural, assim como Joaninha de A Cidade e as Serras.

O ambiente rural, aliás, será percebido como uma possível solução para o problema existencial de Jacinto, que afirma viver há trinta e quatro anos em uma "maçada”. O trecho a seguir sinaliza as significativas alterações que começam a ser observadas na conduta do personagem:

No começo do inverno, porém, notei com inquietação que Jacinto já não folheava o Eclesiastes, desleixava Schopenhauer. Nem festas, nem teosofismos, nem os seus hospícios, nem os fios do Times, pareciam interessar agora o meu amigo, mesmo como demonstrações gloriosas da sua crença. E a sua abominável função de novo se limitou a bocejar, a passar os dedos moles sobre a face pendida, palpando a caveira. Incessantemente aludia à morte como a uma libertação. (QUEIRÓS, 1995, p. 119).

A partida para a quinta de Tormes é representada como uma possível cura para o "parisianismo” de Jacinto, uma válvula de escape para a sua obsessão por tudo o que vem da França e por tudo o que a metrópole cosmopolita representa. Daí a necessidade de voltar a Portugal e ir viver não na capital Lisboa, mas no interior, o que evidenciaria uma rejeição a certos valores personificados pela vida urbana. Uma das representações deste repúdio é o extravio das bagagens de Jacinto na ida para o campo, sem falar na incorporação das leituras de autores da Antiguidade clássica, entre eles Virgílio e Teócrito. Ao reencontrar seu amigo, José Fernandes acredita estar diante de outra pessoa:

Sobre a sua arrefecida palidez de supercivilizado, o ar montesino, ou vida mais verdadeira, espalhara um rubor trigueiro e quente de sangue renovado que o virilizava soberbamente. Dos olhos, que na cidade andavam sempre tão crepusculares e desviados do mundo, saltava um brilho de meio-dia, resoluto e largo, contente em se embeber na beleza das coisas. Até o bigode se lhe encrespara. E já não deslizava a mão desencantada sobre a face, mas batia com ela triunfalmente na coxa. Que sei? Era um Jacinto novíssimo. (QUEIRÓS, 1995, p. 170-171).

O envolvimento de Jacinto com Joaninha, descrita por José Fernandes como uma moça de vinte e cinco anos, “bela, forte, sã e planta da terra”, é também indicativo de uma profunda mudança, bem como da associação entre 
ambiente rural, figura feminina, maternidade e união amorosa duradoura. Em um dos últimos capítulos do romance, Fernandes sintetiza da seguinte maneira a nova vida de Jacinto:

E agora, entre roseiras que rebentam, e vinhas que se vindimam, já cinco anos passaram sobre Tormes e a serra. O meu príncipe já não é o último Jacinto, Jacinto ponto final - porque naquele solar que decaíra, correm agora, com soberba vida , uma gorda e vermelha Terezinha, minha afilhada, e um Jacintinho, senhor muito da a minha amizade. E, pai de família, principiara a fazer-se monótono, pela perfeição da beleza moral, aquele homem tão pitoresco pela inquietação filosófica, e pelos variados tormentos da fantasia insaciada. (QUEIRÓS, 1995, p. 243).

Todos estes elementos remeteriam a uma ferrenha crítica da narrativa à civilização, percebida como algo que retira do sujeito a sua essência vital, ao contrário da vida campesina, que além de promover um verdadeiro reencontro deste mesmo sujeito com as suas raízes, devolve a ele a alegria de viver consumida pela existência cosmopolita. Esta é, aliás, criticada pelo próprio José Fernandes, conforme expresso no trecho a seguir:

E eu atirei, para um montão de lixo, ao canto do pátio, aquele pútrido rebotalho da civilização. E montei. Mas ao dobrar para o caminho empinado da Serra, ainda me voltei, para gritar adeus ao Pimenta, de quem me esquecera. O digno chefe, debruçado sobre o monturo, apanhava, sacudia, recolhia com amor aquelas belas estampas, que chegavam de Paris, contavam as delícias de Paris, derramavam através do mundo a sedução de Paris. (QUEIRÓS, 1995, p. 260).

A “sedução de Paris”, percebida com distanciamento crítico por José Fernandes, é o que explica a enorme repercussão da chegada de Camilo Seabra a Santa Luzia. A maioria dos habitantes da cidade se deslumbra com o "filho do comendador" pelo fato de este ter acabado de chegar da França:

Na cidade e nos seus arredores não se falava em outra coisa. $\mathrm{O}$ assunto, não principal, mas exclusivo das palestras e comentários era o filho do comendador. Ninguém se fartava de o elogiar. Admiravam-lhe as maneiras e a elegância. A mesma superioridade com que ele falava a todos achava entusiastas sinceros. Durante muitos dias foi totalmente impossível que o rapaz pensasse em outra coisa que não fosse contar as suas viagens aos amáveis conterrâneos. Mas pagavam-lhe a maçada, porque a menor coisa que ele dissesse tinha aos olhos dos outros uma graça indefinível. O padre Maciel, que o batizara vinte e sete anos antes, e que o via já homem completo, era o primeiro pregoeiro da sua transformação. (ASSIS, 2008, p. 154).

Camilo se deixa levar pela lisonja de seus conterrâneos, atitude esta que parece ter como finalidade não só ludibriar as pessoas como prolongar ao máximo sua sensação de superioridade: “É perfeitamente inútil dizer que 
o nosso herói omitiu sempre tudo quanto pudesse abalar o bom conceito em que estava no ânimo de todos. A dar-lhe crédito, vivera quase como um anacoreta; e ninguém ousava pensar o contrário.” (ASSIS, 2008, p. 154). Neste ponto da narrativa, torna-se evidente o papel desmistificador assumido pelo narrador, que faz questão de deixar claro o quanto a experiência europeia de Camilo não era tão valiosa quanto parecia a princípio. A novidade em relação à presença do rapaz persiste até quinze dias depois de sua chegada, quando a indiferença sentida em relação à vida cosmopolita também começa a se esgotar: "os campos ficaram monótonos, as árvores monótonas, os rios monótonos, a cidade monótona, ele próprio monótono. Invadiu-o então uma coisa a que podemos chamar - nostalgia do exílio.” (ASSIS, 2008, p. 155). Reforça-se, neste sentido, a noção de que a novidade relativa ao que vem de fora é superficial tanto para os habitantes de Santa Luzia quanto para Camilo, que define seu pertencimento ao Brasil com base na aprovação de sua experiência europeia. Assim sendo, a narrativa nos sugere que o apego aos valores estrangeiros e também, à própria metrópole cosmopolita é efêmero e superável, conforme demonstrará o próprio desenrolar da narrativa.

Camilo está ainda preso às lembranças de Leontina quando começa a se apaixonar por Isabel Matos, que é, aliás, objeto da paixão obsessiva de Leandro Soares, de forma que se estabelece um triângulo amoroso. O protagonista, no entanto, sequer se recorda de que Isabel se apaixonara por ele quando eram crianças, no dia em que colheu uma bela flor azul no alto de uma árvore para presentear a menina. Tal flor é a parasita que confere o título à narrativa, e que se torna uma espécie de fetiche para Isabel. Esta começa a ser cortejada por Camilo, a quem rejeita com veemência, gerando a incompreensão dos habitantes de Santa Luzia. O narrador, todavia, deixa bem claro que o amor de Isabel é direcionado à parasita, "um cadáver de flor, seco, mirrado, uma flor que devia ter sido lindíssima há muito tempo, no pé, mas que hoje, na cestinha em que ela a traz, nenhum sentimento inspira, a não ser de curiosidade. (ASSIS, 2008, p. 166). Na visão de John Gledson (2008), a flor seria uma representação do próprio Camilo, um parasita social que vive às custas do pai e sequer demonstra interesse em exercer a profissão de médico quando retorna ao Brasil. De qualquer forma, a paixão de Camilo por Isabel acaba funcionando como uma neutralização da dicotomia campo versus cidade, uma vez que o protagonista acaba encontrando no Brasil o mesmo que havia encontrado na França. A índole de Isabel pode ser também equiparada à de Leontina Caveau, no sentido de que ambas as mulheres enganam Camilo, a segunda de forma maliciosa, e a primeira de forma a esconder seu amor de infância por ele, metaforizado pela parasita azul. Dessa forma, apesar de representada a princípio como uma simples moça interiorana, Isabel apresenta um comportamento que carrega a mesma complexidade inicialmente atribuída aos habitantes de uma grande cidade, colaborando para desfazer as separações estanques entre o ambiente urbano e o rural. 
Tais separações se verificam em A Cidade e as Serras, mais especificamente a partir do momento em que Jacinto decide abrir mão de sua agitada vida cosmopolita para viver em Tormes. Contudo, ao final do romance, o protagonista decide introduzir algumas inovações tecnológicas na vila, a fim de melhorar a vida de seus habitantes:

Visitara já as suas propriedades de Montemor, da Beira; e consertava, mobiliava as velhas casas dessas propriedades para que os seus filhos, mais tarde, crescidos, encontrassem "ninhos feitos". Mas onde eu reconheci que definitivamente um perfeito e ditoso equilíbrio se estabelecera na alma do meu príncipe, foi quando ele, já saído daquele primeiro e ardente fanatismo da simplicidade - entreabriu a porta de Tormes à civilização. Dois meses antes de nascer a Teresinha, uma tarde, entrou pela avenida de plátanos uma chiante e longa fila de carros, requisitados por toda a freguesia, e acumulados de caixotes. Eram os famosos caixotes, por tanto tempo encalhados em Alba de Tormes, e que chegavam, para despejar a cidade sobre a serra. Eu pensei: - Mau! O meu pobre Jacinto teve uma recaída! Mas os confortos mais complicados, que continha aquela caixotaria imensa, foram, com surpresa minha, desviados para os sótãos imensos, para o pó da inutilidade; e o velho solar apenas se regalou com alguns tapetes sobre os seus soalhos, cortinas pelas janelas desabrigadas, e fundas poltronas, fundos sofás, para que os repousos, por que ele suspirava, fossem mais lentos e suaves. Atribuí esta moderação a minha prima Joaninha, que amava Tormes na sua nudez rude. Ela jurou que assim o ordenara o seu Jacinto. Mas decorridas semanas, tremi. Aparecera, vindo de Lisboa, um contramestre, com operários, e mais caixotes, para instalar um telefone!

- Um telefone, em Tormes, Jacinto?

O meu príncipe explicou, com humildade:

- Para a casa de meu sogro!... Bem vês.

Era razoável e carinhoso. O telefone porém, sutilmente, mudamente, estendeu outro longo fio, para Valverde. E Jacinto, alargando os braços, quase suplicante:

- Para casa do médico. Compreendes....

Era prudente. Mas certa manhã, em Guiães, acordei aos berros da tia Vicência! Um homem chegara, misterioso, com outros homens, trazendo arame, para instalar na nossa casa o novo invento. Sosseguei a tia Vicência, jurando que essa máquina nem fazia barulho, nem trazia doenças, nem atraía as trovoadas. (QUEIRÓS, 1995, p. 243-244).

Esta longa citação nos oferece a possibilidade de problematizar a dicotomia campo idealizado versus cidade corrompida, considerando que, ao instalar uma rede telefônica em Tormes, Jacinto demonstra reconhecer as utilidades de certas inovações tecnológicas para a vida no ambiente rural, em especial no que diz respeito a facilitar a comunicação entre as pessoas. Sintomático disto é também o achado dos caixotes que haviam se perdido na mudança para o campo, bem como o uso de certos móveis e peças de decoração na nova casa de Jacinto, o que, de acordo com José Fernandes, 
seria sinal de um equilíbrio entre tradição e modernidade, percebido como uma evolução no espírito de seu amigo. Portanto, ainda que o romance de Eça aponte uma série de vantagens da vida no campo sobre a vida na cidade, ele também nos possibilita uma leitura segundo a qual certos aspectos positivos de ambos os espaços podem ser integrados para o bem de todos. Dessa forma, ao tomar a decisão de viver no campo e depois, de levar um pouco de progresso e tecnologia para a quinta de Tormes, Jacinto demonstra ter superado a postura acrítica que caracterizara sua vivência parisiense, assim como o deslumbramento experimentado quando se mudou para o campo.

Em “A parasita azul”, a dicotomia apontada acima também se desfaz a partir do momento em que se descobre que o comportamento de Isabel Matos em relação a Camilo Seabra pode ser tão enganador quanto o de Leontina Caveau. Há ainda a desmistificação do mito do conquistador inveterado parisiense, uma vez que Camilo, incapaz de conquistar Isabel por conta própria, pede ajuda a Miguel, um simples homem do campo cuja esposa fora mucama na casa do dr. Matos. É Miguel, aliás, quem relata a Camilo a história da parasita, dando ao protagonista esperanças de ganhar o coração da moça: “Oh! sim! sim! - disse Camilo. - Sou amado! Sou amado!” (ASSIS, 2008, p. 168). Ainda assim, Isabel recusa o amor do rapaz com base na ideia de que seu amor é mais antigo do que o dele: “Apenas isso, concluía Isabel. Quanto a ser sua esposa, nunca. Eu quisera entregar a minha vida a quem tivesse um amor igual ao meu. O seu amor é de ontem; o meu é de nove anos; a diferença de idade é grande demais; não pode ser bom consórcio. Esqueça-me e adeus.” (ASSIS, 2008, p. 169). Esta passagem da narrativa revela o quanto a experiência cosmopolita parisiense fora capaz de obliterar a visão sentimental de Camilo, inicialmente presa a Leontina e à vida boêmia na capital francesa e alheia ao flerte infantil que motivou o amor de Isabel. A resistência da moça cai por terra após a tentativa de suicídio de Camilo, situação esta que, ao que tudo indica, foi arquitetada com a ajuda de Miguel, conforme sinaliza o trecho abaixo:

No fim de uma semana foi o dr. Matos procurado na sua fazenda pelo nosso já conhecido morador da cabana, que ali chegou ofegante e alegre.

- Está salvo! - disse ele.

- Salvo! - exclamaram o pai e a filha.

- É verdade - disse Miguel - fui encontrá-lo no fundo de uma ribanceira, quase sem vida, ontem de tarde.

- E por que não vieste dizer-nos?... - perguntou o velho.

- Porque era preciso cuidar dele em primeiro lugar. Quando voltou a si quis outra vez tentar contra os seus dias; eu e minha mulher impedimo-lo de fazer tal. Está ainda um pouco fraco; por isso não veio comigo. (ASSIS, 2008, p. 171).

Torna-se clara a dependência nutrida por Camilo em relação aos outros, ainda mais no que diz respeito à arte da conquista, algo que ele pa- 
recia dominar muito bem. A narrativa de Machado aponta, portanto, para a desconstrução de determinadas representações de campo e cidade, dicotomia esta neutralizada pelo foco na intriga amorosa e pela representação da figura feminina. Tais aspectos estão também presentes em A Cidade e as Serras, ainda que a princípio a separação entre ambiente urbano e ambiente rural pareça mais estanque, assim como a dicotomização entre a mulher citadina, representada por madame Colombe, e a mulher interiorana, simbolizada por Joaninha.

Um ano após o casamento com Isabel, Camilo recebe em sua fazenda a visita de um viajante francês, que lhe traz vários jornais parisienses: "Lembravam-lhe a vida que ele tivera durante longos anos, e posto nenhum desejo sentisse de trocar por ela a vida atual, havia sempre uma natural curiosidade em despertar recordações de outro tempo.” (ASSIS, 2008, p. 174-175). Percebe-se, neste trecho, a persistência de um certo fascínio em relação a Paris, que parece se desfazer quando Camilo lê a seguinte notícia:

Uma célebre Leontina Caveau, que se dizia viúva de um tal príncipe Alexis, súdito do tzar, foi ontem recolhida à prisão: a bela dama (era bela!) não contente de iludir alguns moços incautos, alapardou-se com todas as joias de uma sua vizinha, mlle. B... A roubada queixou-se a tempo de impedir a fuga da pretendida princesa. (ASSIS, 2008, p. 175).

O trecho acima pode ser interpretado como uma crítica, ainda que sutil, ao deslumbramento com a metrópole cosmopolita parisiense, que engana o sujeito a ponto de este não conseguir identificar a verdadeira índole das pessoas. Tal crítica se torna ainda mais clara quando Camilo diz a Isabel que sente saudades dela e não de Paris, corroborando metaforicamente a ideia de que a referência francesa perdera o sentido diante da nova realidade do sujeito. Assim sendo, o conto de Machado estaria também apontando para o arrefecimento do hábito de se assimilar passivamente o que vem de fora, mostrando o quanto tal hábito pode se revelar limitado e enganador, uma vez que conduz à mistificação e à perda do senso crítico. Tal arrefecimento também aparece em A Cidade e as Serras, evidenciando-se a partir do já citado estabelecimento de um equilíbrio entre vida cosmopolita e vida rural. Torna-se possível, portanto, equiparar as duas narrativas, no sentido de que ambas acabam por veicular uma crítica ao caráter alienante da modernidade e do cosmopolitismo associado à França, defendendo, ainda que implicitamente, a ideia de que a vida citadina pode não ser o único parâmetro para a constituição identitária do sujeito. Nesse sentido, Antonio Candido afirma que Eça

vergasta com ironia e sarcasmo a impotência da sociedade do seu país para resolver as próprias oposições históricas; para escolher entre a continuação do estilo agrário, da sociedade aldeã, e o sentido moderno, isto é, urbano, da civilização oitocentista, que no limite implica em supressão da vida 
rural como estilo e como cultura, embora não como atividade econômica. (CANDIDO, 1978, p. 35).

O texto de Machado, por sua vez, veicula uma crítica não só à alienação causada pela modernidade francesa, mas ao caráter ufanista do nacionalismo romântico. Tal crítica pode ser constatada no famoso ensaio "Instinto de nacionalidade”, que foi, aliás, publicado um ano depois de “A parasita azul”. Nele, Machado afirma que o índio e a natureza não poderiam e nem deveriam ser os únicos parâmetros para a representação da identidade nacional, o que remete a uma busca por paradigmas diferenciados para a constituição desta mesma identidade. De forma semelhante, Eça talvez estivesse, a partir da história de Jacinto, refletindo sobre os rumos de seu próprio país, bem como sobre as maneiras pelas quais a modernização se estabeleceu em Portugal, considerando a dependência em relação aos modelos estrangeiros.

\section{Considerações finais}

Com base em tudo o que foi exposto, podemos considerar tanto Machado de Assis quanto Eça de Queirós como escritores que pensaram lucidamente a respeito da modernidade e do transplante cultural de ideias que se observa nas literaturas portuguesa e brasileira. A análise comparativa entre A Cidade e as Serras e "A parasita azul” nos permitiu identificar determinadas representações de campo e cidade que são problematizadas e desconstruídas por ambos os autores a fim de veicular uma crítica e, por que não dizer, uma possível solução para os impasses relacionados à assimilação passiva do modelo estrangeiro. Assim sendo, constata-se a possibilidade de expandir as relações entre Machado e Eça para além da polêmica em relação a O primo Basílio, evidenciando aspectos que, apesar de pouco explorados, se revelam de fundamental importância para a compreensão das dinâmicas literárias brasileira e portuguesa do século XIX.

\section{Referências}

ASSIS, M. de. Obra completa. Rio de Janeiro: Nova Aguilar, 2008.

CANDIDO, A. Tese e antítese. São Paulo: Companhia Editora Nacional, 1978.

CASANOVA, P. A República Mundial das Letras. Tradução de Marina Guaspari. São Paulo: Companhia das Letras, 2002.

FRANCHETTI, P. Eça e Machado: críticas de ultramar. In: GUIDIN, M. L; GRANJA, L; RICIERI, F. W. (orgs). Machado de Assis: ensaios da crítica contemporânea. São Paulo: Editora UNESP, 2008. p. 269-280.

GLEDSON, J. 1872: “A parasita azul” ficção, nacionalismo e paródia. 
Cadernos de Literatura Brasileira: Machado de Assis, São Paulo, v. 2324, p. 163-218, 2008.

MEDINA, J. Eça político. Lisboa: Seara Nova, 1974.

QUEIRÓS, E. de. A Cidade e as Serras. São Paulo: FTD, 1995.

ROCHA, J. C. C. Machado de Assis e Eça de Queirós: formas de apropriação. Floema,

n. 9, p. 119-146, jan./jun. 2011

TEZZA, C. Mundo urbano e mundo rural nos contos do mestre. Cadernos de Literatura Brasileira: Machado de Assis, São Paulo, v. 23-24, p. 240251, 2008.

VASCONCELOS, S. Romances sem fronteiras. In: ESCOLA SÃO PAULO DE ESTUDOS AVANÇADOS, 2012. Anais... Campinas: Unicamp, 2012.

WILLIAMS, R. O campo e a cidade na história e na literatura. Tradução de Paulo Henriques Britto. São Paulo: Companhia das Letras, 1989.

Recebido em novembro/2015

Aceito em dezembro/2015 